\title{
Methylated trivalent arsenicals are potent inhibitors of glucose stimulated insulin secretion by murine pancreatic islets
}

\author{
Christelle Douillet $^{a}$, Jenna Currier ${ }^{b}$, Jesse Saunders ${ }^{a}$, Wanda M. Bodnar ${ }^{c}$, Tomáš \\ Matoušek $^{\mathrm{d}}$, and Miroslav Stýblo ${ }^{\mathrm{a},{ }^{*}}$ \\ aDepartment of Nutrition, Gillings School of Global Public Health, 2302 MHRC, University of North \\ Carolina at Chapel Hill, Chapel Hill, NC 27599-7461, USA \\ ${ }^{b}$ Curriculum in Toxicology, University of North Carolina at Chapel Hill, Chapel Hill, NC \\ 27599-7461, USA \\ 'Department of Environmental Sciences and Engineering, University of North Carolina at Chapel \\ Hill, Chapel Hill, NC 27599-7431, USA \\ dInstitute of Analytical Chemistry of the ASCR, v.v.i., Veveři 97, 60200 Brno, Czech Republic
}

\begin{abstract}
Epidemiologic evidence has linked chronic exposure to inorganic arsenic (iAs) with an increased prevalence of diabetes mellitus. Laboratory studies have identified several mechanisms by which iAs can impair glucose homeostasis. We have previously shown that micromolar concentrations of arsenite (iAs ${ }^{\mathrm{III}}$ ) or its methylated trivalent metabolites, methylarsonite (MAs ${ }^{\mathrm{III}}$ ) and dimethylarsinite (DMAs ${ }^{\mathrm{III}}$ ), inhibit the insulin-activated signal transduction pathway, resulting in insulin resistance in adipocytes. Our present study examined effects of the trivalent arsenicals on insulin secretion by intact pancreatic islets isolated from C57BL/6 mice. We found that 48-hour exposures to low subtoxic concentrations of iAs ${ }^{\mathrm{III}}$, MAs ${ }^{\mathrm{III}}$ or DMAs ${ }^{\mathrm{III}}$ inhibited glucosestimulated insulin secretion (GSIS), but not basal insulin secretion. MAs ${ }^{\mathrm{III}}$ and DMAs ${ }^{\mathrm{III}}$ were more potent than iAs ${ }^{\mathrm{III}}$ as GSIS inhibitors with estimated $\mathrm{IC}_{50} \unlhd \mathbf{} \mathbf{} .1 \mu \mathrm{M}$. The exposures had little or no effects on insulin content of the islets or on insulin expression, suggesting that trivalent arsenicals interfere with mechanisms regulating packaging of the insulin transport vesicles or with translocation of these vesicles to the plasma membrane. Notably, the inhibition of GSIS by iAs ${ }^{\text {III }}$, MAs ${ }^{\mathrm{III}}$ or DMAs ${ }^{\mathrm{III}}$ could be reversed by a 24-hour incubation of the islets in arsenic-free medium. These results suggest that the insulin producing pancreatic $\beta$-cells are among the targets for iAs exposure and that the inhibition of GSIS by low concentrations of the methylated metabolites of iAs may be the key mechanism of iAs-induced diabetes.
\end{abstract}

\section{Keywords}

Arsenic; Diabetes; Isolated pancreatic islets; $\beta$-Cells; Insulin secretion

\section{Introduction}

Arsenic (As) is a naturally occurring toxic metalloid commonly found in ground and surface water reservoirs. Tens of millions of people worldwide are currently exposed to high levels

\footnotetext{
(c) 2012 Elsevier Inc. All rights reserved.

*Corresponding author. Fax: +1 919843 0776. styblo@med.unc.edu (M. Stýblo).

Conflict of interest statement

The authors declare that there are no conflicts of interest.
} 
of inorganic arsenic (iAs) in drinking water (BGS and DPHE, 2001; The World Bank, 2005). At least 13 million U.S. residents drink water containing iAs at levels higher than the current EPA maximum contaminant level of $10 \mu \mathrm{g}$ As/L (ATSDR, 2007). Although the focus of public health and regulatory agencies has traditionally been on the carcinogenic effects of iAs, epidemiological evidence suggests that even greater numbers of people exposed to iAs are at risk of developing non-cancerous diseases, including diabetes mellitus. A panel of experts assembled by the NIEHS National Toxicology Program (NTP) in January 2011 agreed that existing data in humans support an association between diabetes and high exposures to iAs in drinking water ( $\geq 150 \mathrm{ppb} A s)$; however, the evidence is insufficient to conclude that diabetes is associated with low-to-moderate exposures ( $<150 \mathrm{ppb}$ As) (Maull et al., 2012). This panel also concluded that the animal and in vitro studies implicate several pathways by which iAs can influence pancreatic $\beta$-cell function and insulin sensitivity.

Diabetes associated with iAs exposure has been historically referred to as type 2 diabetes (Longnecker and Daniels, 2001; Maull et al., 2012; Navas-Acien et al., 2006). However, little information has been provided on the mechanisms underlying this disease. We have shown that subtoxic micromolar concentrations of arsenite (iAs ${ }^{\mathrm{III}}$ ) and its methylated trivalent metabolites, methylarsonite (MAs ${ }^{\mathrm{III}}$ ) and dimethylarsinite (DMAs ${ }^{\mathrm{III}}$ ), inhibit the insulin-dependent phosphorylation of PKB/Akt by PDK, thus suppressing the insulinstimulated glucose uptake in adipocytes (Paul et al., 2007a, 2008; Walton et al., 2004). DMAs ${ }^{\text {III }}$ did not inhibit PKB/Akt phosphorylation, but interfered with insulin signaling downstream from $\mathrm{PKB} / \mathrm{Akt}$. While these results are consistent with insulin resistance typically associated with type 2 diabetes, other studies have shown that iAs can also target the mechanisms regulating glucose-stimulated insulin secretion (GSIS) by pancreatic $\beta$ cells.

GSIS is a biphasic process (Rorsman et al., 2000). The 1st phase is initiated by the uptake and oxidative metabolism of glucose, resulting in an increased production of ATP and depolarization of plasma membrane, followed by influx of extracellular calcium ions and activation of $\mathrm{Ca}^{2+}$-dependent calmodulin protein kinases that phosphorylate proteins associated with insulin secretory vesicles, the ion channels, and the cytoskeletal structure. The 2nd phase of GSIS involves an ATP-dependent mobilization of storage pool granules to the cell surface to sustain insulin release. Results of previous studies suggest several mechanisms by which iAs could interfere with GSIS: (i) Like glucose, iAs ${ }^{\mathrm{III}}$ is transported across the plasma membrane by GLUT transporters (Liu et al., 2006) and thus, could compete with glucose uptake by $\beta$-cells. (ii) iAs ${ }^{\text {III }}$ modulates expression of hexokinase, the enzyme that helps to control flux of glucose-6-phosphate into glycolysis (Pysher et al., 2007). (iii) iAs III forms a stable complex with dihydrolipoamide, a cofactor of pyruvate dehydrogenase and a-ketoglutarate dehydrogenase, the key enzymes in the oxidative metabolism of glucose (Tsen, 2004). (iv) iAs ${ }^{\mathrm{III}}$ inhibits calpain-10 (Díaz-Villaseñor et al., 2008), the $\mathrm{Ca}^{2+}$-dependent protease that activates SNAP-25 (a member of the insulin secretory machinery) (Turner, 2007). (v) Finally, arsenate (iAs ${ }^{\mathrm{V}}$ ), the product of iAs ${ }^{\mathrm{III}}$ oxidation, can interfere with ATP synthesis by replacing phosphate in the reactions of oxidative phosphorylation in mitochondria (Gresser, 1981). Another mechanism has been proposed by a recent study using rat insulinoma (INS-1) cells. Here, exposure to iAs ${ }^{\text {III }}$ was shown to provoke an adaptive oxidative stress response that increased antioxidant levels and dampened signaling involving reactive oxygen species that is thought to be essential for regulation of GSIS (Fu et al., 2010).

Notably, all the above studies examined only effects of iAs species, iAs ${ }^{\mathrm{III}}$ and iAs ${ }^{\mathrm{V}}$. In addition, most of these studies used insulinoma cell lines which differ from the insulin secreting pancreatic islets by their morphology, level of differentiation, insulin content and, most importantly by their abnormal response to glucose stimulation. The present study used 
intact isolated pancreatic islets to compare the effects of iAs ${ }^{\mathrm{III}}$ with effects of its methylated trivalent metabolites, MAs ${ }^{\mathrm{III}}$ and DMAs ${ }^{\mathrm{III}}$, which are more reactive and more toxic than either iAs ${ }^{\mathrm{III}}$ or iAs ${ }^{\mathrm{V}}$ (Styblo et al., 2000, 2002; Thomas et al., 2001). Our results show that both MAs ${ }^{\mathrm{III}}$ and DMAs ${ }^{\mathrm{III}}$ are more potent than iAs ${ }^{\mathrm{III}}$ as inhibitors of GSIS and that the inhibition of GSIS by trivalent arsenicals can be reversed by incubating the islets in As-free medium.

\section{Materials and methods \\ Isolated pancreatic islets}

Pancreatic islets were isolated from adult male C57BL/6 mice (Charles River Laboratories, Wilmington, MA). All procedures involving mice were approved by the University of North Carolina Institutional Animal and Use Committee. Mice were sacrificed by cervical dislocation and pancreas was infused in situ with collagenase $\mathrm{P}(1 \mathrm{mg} / \mathrm{ml}$, Roche Diagnostics Corp., Indianapolis, IN) via the common bile duct. Pancreas was then removed and digested in the collagenase solution for $12 \mathrm{~min}$ at $37^{\circ} \mathrm{C}$. The digestate was washed and islets were purified by centrifugation in a gradient of Ficoll PM 400 (GE Healthcare, Uppsala, Sweden) (Szot et al., 2007).

\section{Treatment}

The isolated islets were cultivated overnight at $37{ }^{\circ} \mathrm{C}$ with $5 \% \mathrm{CO}_{2}$ in RPMI 1640 medium (Mediatech, Manassas, VA) with 10\% fetal bovine serum, $10 \mathrm{mM}$ Hepes, $1 \mathrm{mM}$ sodium pyruvate, $100 \mathrm{U} / \mathrm{ml}$ penicillin, and $100 \mu \mathrm{g} / \mathrm{ml}$ streptomycin (all from Sigma-Aldrich, St. Louis, MO). The same medium was used in experiments in which the islets were exposed to iAs ${ }^{\text {III }}$ (sodium arsenite; Sigma-Aldrich), MAs ${ }^{\text {III }}$ (methylarsine oxide) or DMAs ${ }^{\text {III }}$ (iododimethylarsine). MAs ${ }^{\mathrm{III}}$ and DMAs ${ }^{\mathrm{III}}$ were provided by Dr. William Culllen (University of British Columbia, Vancouver, Canada). To limit oxidation of trivalent arsenicals, the culture medium was replaced every $24 \mathrm{~h}$ with medium containing freshly prepared arsenicals.

\section{Speciation analysis of As}

The concentrations and metabolism of arsenicals in the islets were monitored by hydride generation (HG)-cryotrapping (CT)-inductively coupled plasma-mass spectrometry (ICPMS), using Agilent 7500cx ICP-MS system (Agilent Technologies, Santa Clara, CA) and the HG-CT components and procedures previously described for HG-CT-atomic absorption spectrometry (AAS) technique for speciation analysis of As in biological samples (Hernández-Zavala et al., 2008; Matoušek et al., 2008) (see Supplementary Materials for details).

\section{Static GSIS assay}

Islets exposed to arsenicals or control, unexposed islets ( 15 islets/assay) were transferred into a glucose-free buffer containing $114 \mathrm{mM} \mathrm{NaCl}, 4.7 \mathrm{mM} \mathrm{KCl}, 1.2 \mathrm{mM} \mathrm{KH}_{2} \mathrm{PO}_{4}, 1.16$ $\mathrm{mM} \mathrm{MgSO}_{4}, 20 \mathrm{mM}$ Hepes, $2.5 \mathrm{mM} \mathrm{CaCl}_{2}, 0.2 \%$ bovine serum albumin, and $25.5 \mathrm{mM}$ $\mathrm{NaHCO}_{3}$ (all from Sigma-Aldrich) for $1 \mathrm{~h}$ at $37{ }^{\circ} \mathrm{C}$ and $5 \% \mathrm{CO}_{2}$, followed by a 1-hour incubation with $2.5 \mathrm{mM}$ glucose (Sigma-Aldrich) and 1-hour incubation with $16.7 \mathrm{mM}$ glucose (Boucher et al., 2004). Medium from each incubation step was frozen and stored for insulin analysis. Insulin concentrations were determined using Rat/Mouse Insulin ELISA kit from Millipore (Billerica, MA). The 3-[4,5-dimethylthiazol-2-yl]-2,5-diphenyltetrazolium bromide (MTT) assay (Styblo et al., 2002) was used to monitor islet viability. 


\section{Quantitative PCR (qPCR)}

Islet RNA was extracted using RNEasy Micro kit with on column DNAse treatment (Qiagen, Valencia, CA), and analyzed by a Nanodrop 2000c spectrophotometer (ThermoScientific, Waltham, MA). cDNA was prepared using random primers and Superscript III reverse transcriptase (Invitrogen, Carlsbad, CA). The transcripts of two mouse insulin genes (Ins1 and Ins2) and 18S RNA were quantified using the corresponding Taqman assays with Fast Universal PCR master mix (Applied Biosystems, Foster City, CA) and Lightcycler 480 II instrument and software 1.5.0 (Roche).

\section{Statistical analysis}

Data were analyzed by ANOVA and Fisher's PLSD tests using StatView 5.0.1 software (SAS institute, Cary, NC). Data are represented as mean \pm standard error (SE). Differences between treatments with $\mathrm{p}<0.05$ were considered statistically significant.

\section{Results and discussion}

The iAs-induced diabetes has been referred to as type 2 diabetes because of the adult onset of the disease and absence of ketoacidosis which is typically associated with type 1 diabetes (Haller et al., 2005). The onset and early stages of type 2 diabetes are characterized by insulin resistance, i.e., nonresponsiveness to insulin signaling leading to impaired uptake of glucose in peripheral tissues, and hyperinsulinemia due to a compensatory increase of insulin production by $\beta$-cells. The continued insulin resistance ultimately leads to the pancreatic $\beta$-cell failure (Prentki and Nolan, 2006). However, results of our recent laboratory and population studies suggest that the phenotype of diabetes associated with iAs exposure may differ from that of type 2 diabetes. Specifically, we have shown that exposure of $\mathrm{C} 57 \mathrm{Bl} / 6$ mice to iAs alone or combined with high-fat diet produced diabetes which is characterized by low insulin resistance (HOMA-IR) and impaired insulin production in response to glucose challenge (Paul et al., 2007b, 2011). Similarly, we found negative correlations between iAs exposure and fasting plasma insulin and HOMA-IR among residents of the Zimapan and Lagunera regions in Mexico who drank water containing iAs (up to $215 \mu \mathrm{g} \mathrm{As} / \mathrm{L}$ ) (Del Razo et al., 2011). Taken together these data point to $\beta$-cells as a primary target for the diabetogenic effects of iAs exposure and to an impaired GSIS as the key mechanism of iAs-induced diabetes. The present study used pancreatic islets isolated from $\mathrm{C} 57 \mathrm{Bl} / 6$ mice to examine effects of iAs and its toxic methylated trivalent metabolites on GSIS.

The islets used in this study were fully functional as documented by a strong response to glucose stimulation, i.e., 10-15-fold increase in insulin secretion by control (untreated) islets treated with $16.7 \mathrm{mM}$ glucose (Fig. 1A). Exposures to low sub-micromolar or micromolar concentrations of trivalent arsenicals for $48 \mathrm{~h}$ significantly decreased GSIS in islets stimulated with $16.7 \mathrm{mM}$ glucose, but had no effects on basal insulin secretion by islets incubated with $2.5 \mathrm{mM}$ glucose. Notably, MAs ${ }^{\mathrm{III}}$, and particularly DMAs ${ }^{\mathrm{III}}$ were more potent than iAs ${ }^{\mathrm{III}}$ as GSIS inhibitors, decreasing insulin secretion by $>50 \%$ at the concentration of $0.1 \mu \mathrm{M}$. These exposures, however, did not affect the total insulin content in the culture; i.e., the amount of insulin secreted in response to glucose stimulation plus the amount of insulin remaining in the stimulated islets (Fig. 1B). Results of a previous study using primary rat $\beta$-cells have suggested that a 144 -hour exposure to cytotoxic $5 \mu \mathrm{M}$ iAs ${ }^{\mathrm{III}}$ suppresses insulin expression (Díaz-Villaseñor et al., 2006). In the present study, the 48hour exposure to $2 \mu \mathrm{M}$ iAs ${ }^{\text {III }}$ that significantly inhibited GSIS had no effects on Ins1 or Ins2 mRNA levels (Fig. 1C). Similarly, $0.5 \mu \mathrm{M}$ MAs ${ }^{\mathrm{III}}$ and $1 \mu \mathrm{M}$ DMAs ${ }^{\mathrm{III}}$ decreased Ins1 and/or Ins 2 mRNA levels only by small ( $20 \%)$ margins. The concentrations of arsenicals used in this study did not decrease islet viability (Fig. 1D), indicating that the GSIS impairment was 
not due to loss of $\beta$-cell integrity. Taken together, these results suggest that subchronic exposures to trivalent arsenicals inhibit GSIS by interfering with mechanisms that regulate the assembly and/or secretion of insulin vesicles, but have little effects on de novo insulin synthesis. Consistent with this mode of action were results obtained after treatment of As ${ }^{\text {III }}$ exposed and glucose-stimulated islets with $\mathrm{KCl} . \mathrm{KCl}$ is an insulin secretagogue that depolarizes $\beta$-cell membrane and triggers $\mathrm{Ca}^{2+}$ ion influx, thus increasing exocytosis of the insulin-containing secretory granules independent of glucose stimulation or ATP production (Liang and Matschinsky, 1994). In this study, $\mathrm{KCl}$ treatment overcame the inhibitory effects of arsenicals in glucose-stimulated islets, resulting in a marked increase in insulin secretion (Fig. 2).

We have previously reported that mice exposed to iAs ${ }^{\mathrm{III}}$ developed diabetes (Paul et al., 2007b, 2008, 2011). HG-CT-AAS analyses showed that significant amounts of iAs and its methylated metabolites, MAs and DMAs, were retained in tissues that regulate glucose homeostasis, including liver, pancreas, skeletal muscle and fat. Liver is thought to be the major site for iAs methylation. However, our whole-mouse experiments could not provide information about the origin of the methylated metabolites found in the pancreas. In this study, we used HG-CT-ICP-MS to identify As species retained in the islets exposed for $48 \mathrm{~h}$ to $0.5 \mu \mathrm{M}$ iAs ${ }^{\mathrm{III}}$, MAs ${ }^{\mathrm{III}}$ or DMAs ${ }^{\mathrm{III}}$ and in control (unexposed) islets (Fig. 3). We found the total As levels (i.e., sum of As species) to be higher in islets exposed to MAs ${ }^{\text {III }}$ and DMAs ${ }^{\text {III }}$ as compared to islets exposed to iAs ${ }^{\mathrm{III}}$. This finding is consistent with results of our previous studies (Drobná et al., 2005), suggesting that the methylated trivalent arsenicals are taken up and retained by mammalian cells to a greater extent than iAs ${ }^{\mathrm{III}}$. The HG-CT-ICP-MS analysis also showed that murine pancreatic islets are capable of methylating iAs ${ }^{\mathrm{III}}$ and MAs ${ }^{\text {III }}$. Specifically, DMAs accounted for $\sim 57 \%$ of As in islets exposed to iAs ${ }^{\text {III }}$ or MAs ${ }^{\text {III }}$. DMAs was also found in medium in which the islets exposed to iAs ${ }^{\mathrm{III}}$ or MAs ${ }^{\mathrm{III}}$ were maintained (data not shown). Although we did not determine the oxidation state of As, it is possible that the inhibition of GSIS in islets exposed to iAs ${ }^{\mathrm{III}}$ or MAs ${ }^{\mathrm{III}}$ is at least in part due to the formation of DMAs ${ }^{\mathrm{III}}$. We were able to detect iAs, MAs and DMAs even in control islets. Because the culture medium contained only traces of iAs $(\unlhd 0.5 \mathrm{nM}$ ), the presence of these arsenicals in the islets suggests that mice were exposed in vivo to iAs or methylated arsenicals from diet or the environment. Notably, the control islets contained more iAs but less MAs and DMAs than did the islets exposed to $0.5 \mu \mathrm{M}$ iAs ${ }^{\mathrm{III}}$, suggesting again that the methylated arsenicals are responsible for GSIS inhibition. Future studies using pancreatic islets from mice knocked out for As3mt (Hughes et al., 2010), the key enzyme in the methylation pathway for iAs, will help us to better characterize the potentials of individual As ${ }^{\text {III }}$ species to inhibit GSIS.

We have recently reported that chronic exposure to iAs in drinking water is associated with an increased risk of diabetes in the Zimapan and Lagunera regions in Mexico (Del Razo et al., 2011). Here, the risk of diabetes was associated only with the current levels of iAs in drinking water, but not with iAs levels recorded in the local water supplies during previous years or with cumulative exposure. These findings indicate that iAs-induced diabetes could be a temporary, possibly reversible condition that lasts only as long as the exposure lasts, i.e., as long as iAs or its metabolites are present in the target tissues. To test the reversibility hypothesis in this study, we examined GSIS by isolated pancreatic islets that were exposed to $2 \mu \mathrm{M}$ iAs ${ }^{\mathrm{III}}, 0.5 \mu \mathrm{M} \mathrm{MAs}^{\mathrm{III}}$ or $0.5 \mu \mathrm{M} \mathrm{DMAs}^{\mathrm{III}}$ for $24 \mathrm{~h}$ and then let to recover for additional $24 \mathrm{~h}$ in As-free medium (Fig. 4). The 24-hour exposures inhibited GSIS to somewhat lesser extent than the 48-hour exposures described in Fig. 1. Notably, we found that the 24-hour incubation in As-free medium restored GSIS to the levels that were not significantly different from GSIS in control, unexposed islets. Thus, the inhibition of GSIS by trivalent arsenical was reversed when the exposure was discontinued. However, significance of these findings is uncertain. The time of exposure in this study was limited by 
viability of isolated pancreatic islets, which usually do not survive in culture for longer than 4 days after isolation. It is possible that longer exposures would result in permanent changes and irreversible inhibition of GSIS. Thus, the reversibility of GSIS inhibition by long-term exposures to trivalent arsenicals needs to be examined in laboratory studies using $\beta$-cell lines and mice or, preferably, in epidemiologic studies involving human populations chronically exposed to iAs.

In summary, our results show that trivalent arsenicals, and specifically the methylated trivalent metabolites MAs ${ }^{\mathrm{III}}$ and DMAs ${ }^{\mathrm{III}}$ are potent inhibitors of GSIS by pancreatic islets. In a broader context, these results provide new evidence that iAs exposure targets pancreatic $\beta$-cells and that inhibition of insulin secretion by these cells is at least in part responsible for the diabetogenic effects of iAs exposure.

\title{
Supplementary Material
}

Refer to Web version on PubMed Central for supplementary material.

\section{Acknowledgments}

\begin{abstract}
Funding
The research presented here was supported by NIH grant no. 5R01 ES015326 to Miroslav Styblo, by a grant from the Ministry of Education, Youth and Sports of the Czech Republic Kontakt II program (project no. LH12040), and by AS CR institutional fund RVO: 68081715. Support was also provided by the UNC Nutrition Obesity Research Center funded by the National Institute of Diabetes and Digestive and Kidney Diseases (grant no. DK056350) and by the Center for Environmental Health and Susceptibility funded by the National Institute of Environmental Health Sciences (grant no. P30ES010126).
\end{abstract}

The authors thank Dr. William Cullen (University of British Columbia, Vancouver, Canada) for providing MAs III and DMAs ${ }^{\text {III }}$ for this study.

\section{Abbreviations}

\begin{tabular}{|c|c|}
\hline As3mt & arsenic ( +3 oxidation state) methyltransferase \\
\hline ATP & adenosine tri-phosphate \\
\hline DMAs & dimethyl-arsenic \\
\hline DMAs ${ }^{\text {III }}$ & dimethylarsinite \\
\hline ELISA & enzyme-linked immuno-sorbent assay \\
\hline GLUT & glucose transporter \\
\hline GSIS & glucose-stimulated insulin secretion \\
\hline HG-CT-AAS & hydride generation-cryotrapping-atomic absorption spectrometry \\
\hline HG-CT-ICP-MS & $\begin{array}{l}\text { hydride generation-cryotrapping-inductively-coupled plasma-mass } \\
\text { spectrometry }\end{array}$ \\
\hline iAs & inorganic arsenic \\
\hline iAs & arsenite \\
\hline iAs $\mathbf{V}$ & arsenate \\
\hline $\mathbf{I C}_{\mathbf{5 0}}$ & $\begin{array}{l}\text { concentration of an inhibitor at which 50\% inhibition of the response } \\
\text { is seen }\end{array}$ \\
\hline NIEHS & National Institute of Environmental Health Sciences \\
\hline
\end{tabular}




$\begin{array}{ll}\text { MAs } & \text { dimethyl-arsenic } \\ \text { MAs }{ }^{\text {III }} & \text { methylarsonite } \\ \text { MTT } & \text { 3-[4,5-dimethylthiazol-2-yl]-2,5-diphenyltetrazolium bromide } \\ \text { PCR } & \text { polymerase chain reaction } \\ \text { PKA } & \text { protein kinase A } \\ \text { PKB/Akt } & \text { protein kinase B } \\ \text { PKC } & \text { protein kinase C } \\ \text { SE } & \text { standard error to the mean }\end{array}$

\section{References}

ATSDR (Agency for Toxic Substances, Disease Registry). Toxicological Profile for Arsenic. Vol. 2007. U.S. Department of Health and Human Services, Public Health Service; 2007 Aug. http:// www.atsdr.cdc.gov/toxprofiles/tp.asp?id=22\&tid=3

BGS, DPHE. Arsenic contamination of groundwater in Bangladesh. Final report. British Geological Survey Report WC/00/19. 2001; 2

Boucher A, Lu D, Burgess SC, Telemaque-Potts S, Jensen MV, Mulder H, Wang MY, Unger RH, Sherry AD, Newgard CB. Biochemical mechanisms of lipid-induced impairment of glucosestimulated insulin secretion and reversal with a malate analog. J Biol Chem. 2004; 279:27,26327,271 .

Del Razo LM, García-Vargas GG, Valenzuela OL, Hernandez-Castellanos E, Sánchez-Peña LC, Drobná Z, Loomis D, Stýblo M. Exposure to arsenic in drinking water is associated with increased prevalence of diabetes: a cross-sectional study in the Zimapán and Lagunera regions in Mexico. Environ Health. 2011; 10:73. [PubMed: 21864395]

Díaz-Villaseñor A, Sánchez-Soto MC, Cebrián ME, Ostrosky-Wegman P, Hiriart M. Sodium arsenite impairs insulin secretion and transcription in pancreatic beta-cells. Toxicol Appl Pharmacol. 2006; 214:30-34. [PubMed: 16413591]

Díaz-Villaseñor A, Burns AL, Salazar AM, Sordo M, Hiriart M, Cebrián ME, Ostrosky-Wegman P. Arsenite reduces insulin secretion in rat pancreatic beta-cells by decreasing the calcium-dependent calpain-10 proteolysis of SNAP-25. Toxicol Appl Pharmacol. 2008; 231:291-299. [PubMed: 18597805]

Drobná Z, Waters SB, Devesa V, Harmon AW, Thomas DJ, Stýblo M. Metabolism and toxicity of As in human urothelial cells expressing rat arsenic ( +3 oxidation state) methyltransferase. Toxicol Appl Pharmacol. 2005; 207:147-159. [PubMed: 16102566]

Fu J, Woods CG, Yehuda-Shnaidman E, Zhang Q, Wong V, Collins S, Sun G, Andersen ME, Pi J. Low-level arsenic impairs glucose-stimulated insulin secretion in pancreatic beta cells: involvement of cellular adaptive response to oxidative stress. Environ Health Perspect. 2010; 118:864-870. [PubMed: 20100676]

Gresser MJ. ADP-arsenate. Formation by submitochondrial particles under phosphorylating conditions. J Biol Chem. 1981; 256:5981-5983. [PubMed: 7240187]

Haller MJ, Atkinson MA, Schatz D. Type 1 diabetes mellitus: etiology, presentation, and management. Pediatr Clin North Am. 2005; 52:1553-1578. [PubMed: 16301083]

Hernández-Zavala A, Matoušek T, Drobná Z, Adair BM, Dědina J, Thomas DJ, Stýblo M. Speciation of arsenic in biological matrices by automated hydride generation-cryotrapping-atomic absorption spectrometry with multiple microflame quartz tube atomizer (multiatomizer). J Anal At Spectrom. 2008; 23:342-351. [PubMed: 18677417]

Hughes MF, Edward BC, Herbin-Davis KM, Saunders RJ, Styblo M, Thomas DJ. Arsenic (+3 oxidation state) methyltransferase genotype affects steady-state distribution and clearance of arsenic in arsenate-treated mice. Toxicol Appl Pharmacol. 2010; 249:217-223. [PubMed: 20887743] 
Liang Y, Matschinsky FM. Mechanisms of action of nonglucose insulin secretagogues. Annu Rev Nutr. 1994; 14:59-81. [PubMed: 7946533]

Liu Z, Sanchez MA, Jiang X, Boles E, Landfear SM, Rosen BP. Mammalian glucose permease GLUT1 facilitates transport of arsenic trioxide and methylarsonous acid. Biochem Biophys Res Commun. 2006; 351:424-430. [PubMed: 17064664]

Longnecker MP, Daniels JL. Environmental contaminants as etiologic factors for diabetes. Environ Health Perspect. 2001; 109:871-876. [PubMed: 11744505]

Matoušek T, Hernández-Zavala A, Svoboda M, Langerová L, Adair BM, Drobná Z, Thomas DJ, Stýblo M, Dědina J. Oxidation state specific generation of arsines from methylated arsenicals based on L-cysteine treatment in buffered media for speciation analysis by hydride generationautomated cryotrapping-gas chromatography-atomic absorption spectrometry with the multiatomizer. Spetrochim Acta Part B. 2008; 63:396-406.

Maull EA, Ahsan H, Edwards J, Longnecker MP, Navas-Acien A, Pi J, Silbergeld EK, Styblo M, Tseng CH, Thayer KA, Loomis D. Evaluation of the Association between Arsenic and Diabetes: A National Toxicology Program Workshop Review. Environ Health Perspect. 2012; 120:1658-1670. [PubMed: 22889723]

Navas-Acien A, Silbergeld EK, Streeter RA, Clark JM, Burke TA, Guallar E. Arsenic exposure and type 2 diabetes: a systematic review of the experimental and epidemiological evidence. Environ Health Perspect. 2006; 114:641-648. [PubMed: 16675414]

Paul DS, Harmon AW, Devesa V, Thomas DJ, Styblo M. Molecular mechanisms of diabetogenic effects of arsenic: inhibition of insulin signaling by arsenite and methylarsonous acid. Environ Health Perspect. 2007a; 115:734-742. [PubMed: 17520061]

Paul DS, Hernández-Zavala A, Walton FS, Adair BM, Dědina J, Matoušek T, Styblo M. Examination of the effects of arsenic on glucose homeostasis in cell culture and animal studies: development of a mouse model for arsenic-induced diabetes. Toxicol Appl Pharmacol. 2007b; 222:305-314. [PubMed: 17336358]

Paul, DS.; Devesa, V.; Hernández-Zavala, A.; Adair, BM.; Walton, FS.; Drobná, Z.; Thomas, DJ.; Styblo, M. Environmental arsenic as a disruptor of insulin signaling. In: Collery, P.; Maymard, I.; Theophanides, T.; Khasanova, L.; Collery, T., editors. Metal Ions in Biology and Medicine. Vol. 10. John Libbey; Eurotext, Paris: 2008. p. 1-7.

Paul DS, Walton FS, Saunders RJ, Styblo M. Characterization of the impaired glucose homeostasis produced in C57BL/6 mice by chronic exposure to arsenic and high-fat diet. Environ Health Perspect. 2011; 119:1104-1109. [PubMed: 21592922]

Prentki M, Nolan CJ. Islet beta cell failure in type 2 diabetes. J Clin Invest. 2006; 116:1802-1812. [PubMed: 16823478]

Pysher MD, Sollome JJ, Regan S, Cardinal TR, Hoying JB, Brooks HL, Vaillancourt RR. Increased hexokinase II expression in the renal glomerulus of mice in response to arsenic. Toxicol Appl Pharmacol. 2007; 224:39-48. [PubMed: 17643460]

Rorsman P, Eliasson L, Renstrom E, Gromada J, Barg S, Gopel S. The cell physiology of biphasic insulin secretion. News Physiol Sci. 2000; 15:72-77. [PubMed: 11390882]

Styblo M, Del Razo LM, Vega L, Germolec DR, LeCluyse EL, Hamilton GA, Reed W, Wang C, Cullen WR, Thomas DJ. Comparative toxicity of trivalent and pentavalent inorganic and methylated arsenicals in human cells. Arch Toxicol. 2000; 74:289-299. [PubMed: 11005674]

Stýblo M, Drobná Z, Jaspers I, Lin S, Thomas DJ. The role of biomethylation in toxicity and carcinogenicity of arsenic: a research update. Environ Health Perspect. 2002; 110(Suppl 5):767771. [PubMed: 12426129]

Szot GL, Koudria P, Bluestone JA. Murine pancreatic isolation. J Viz Exp. 2007; (7):255.

The World Bank. Arsenic contamination of groundwater in Asia. A World Bank and Water and Sanitation Program Report. 2005 Mar.2005 http://siteresources.worldbank.org/ INTSAREGTOPWATRES/Resources/ARSENIC_BRIEF.pdf.

Thomas DJ, Styblo M, Lin S. The cellular metabolism and systemic toxicity of arsenic. Toxicol Appl Pharmacol. 2001; 176:127-144. [PubMed: 11601889]

Tseng $\mathrm{CH}$. The potential biological mechanisms of arsenic-induced diabetes mellitus. Toxicol Appl Pharmacol. 2004; 197:67-83. [PubMed: 15163543] 
Turner MD. Coordinated control of both insulin secretion and insulin action through calpain-10mediated regulation of exocytosis? Mol. Genet Metab. 2007; 91:305-307.

Walton FS, Harmon AW, Paul DS, Drobna Z, Patel YM, Styblo M. Inhibition of insulin-dependent glucose uptake by trivalent arsenicals: possible mechanism of arsenic-induced diabetes. Toxicol Appl Pharmacol. 2004; 198:424-433. [PubMed: 15276423]

\section{Appendix A. Supplementary data}

Supplementary data to this article can be found online at http://dx.doi.org/10.1016/j.taap. 2012.12.007. 



Fig. 1.

Inhibition of glucose stimulated insulin secretion (GSIS) by trivalent arsenicals: $A$, GSIS by pancreatic islets exposed to iAs ${ }^{\mathrm{III}}, \mathrm{MAs}{ }^{\mathrm{III}}$ or DMAs ${ }^{\mathrm{III}}$ for $48 \mathrm{~h}$; mean and standard error (SE) for 4-7 assays with 15 islets per assay are shown $\left({ }^{*} \mathrm{p}<0.05\right.$ and ${ }^{* *} \mathrm{p}<0.01$ for differences between exposed and unexposed islets incubated with $2.5 \mathrm{mM}$ or $16.7 \mathrm{mM}$ glucose). $B$, the islet insulin content and amount of secreted insulin in unexposed islet cultures (Ctrl.) and cultures exposed for $48 \mathrm{~h}$ to arsenicals and stimulated with $16.7 \mathrm{mM}$ glucose; mean and SE for 5-9 assays with 15 islets per assay are shown ( ${ }^{*} \mathrm{p}<0.05$ for differences between exposed and unexposed islets). $C$, Ins 1 and Ins $2 \mathrm{mRNA}$ levels in islets exposed to trivalent arsenicals for $48 \mathrm{~h}$ and in control islets; mean and SE for 4-8 assays with 15 islets per assay are shown ( ${ }^{*} \mathrm{p}<0.05$ for differences between exposed and control islets). $D$, viability of islets exposed to trivalent arsenicals for $48 \mathrm{~h}$ and of control islets measured by MTT assay; mean and SE for 4-9 assays with 15 islets per assay are shown. 


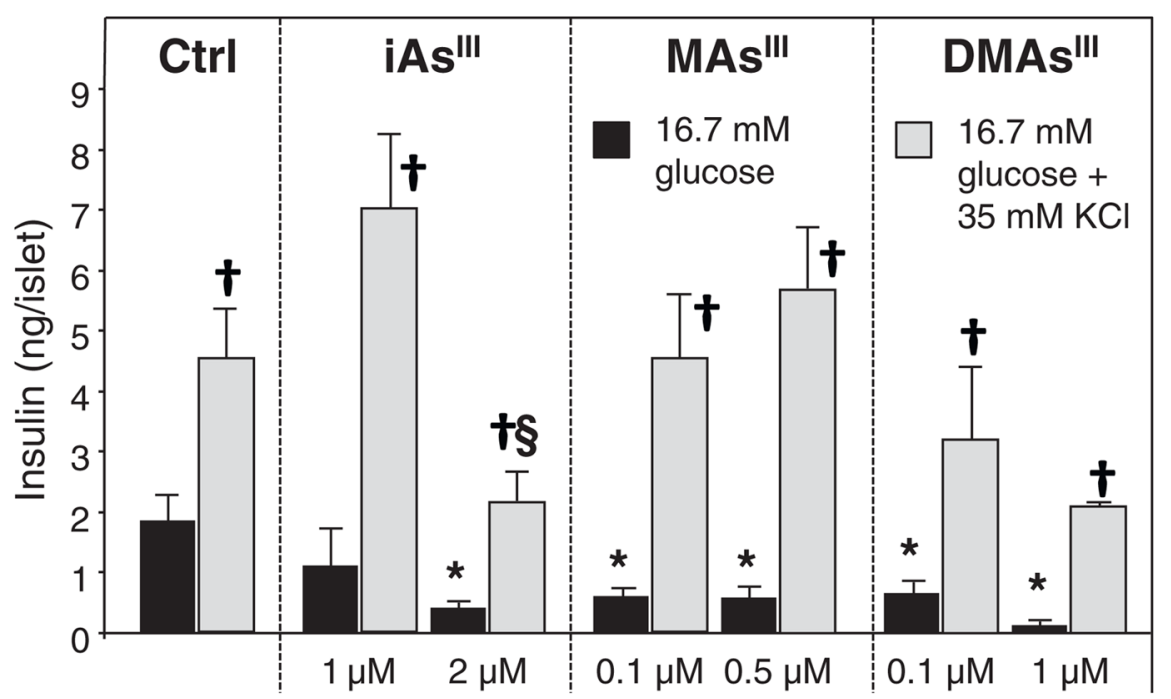

Fig. 2.

Effects of trivalent arsenicals on insulin secretion by pancreatic islets stimulated with 16.7 $\mathrm{mM}$ glucose in presence or absence of an insulin secretagogue, $\mathrm{KCl}(35 \mathrm{mM})$; mean and standard error for $4-10$ assays with 15 islets per assay are shown $\left({ }^{*} \mathrm{p}<0.05\right.$ for differences between exposed and control (Ctrl), unexposed islets stimulated with $16.7 \mathrm{mM}$ glucose in absence of $\mathrm{KCl} ;{ }^{\dagger} \mathrm{p}<0.0001$ for differences between insulin secretion by glucose stimulated islets in the presence and absence of $\mathrm{KCl} ;{ }^{\S} \mathrm{p}<0.02$ for difference between the glucose stimulated and $\mathrm{KCl}$-treated islets exposed to $1 \mu \mathrm{M}$ and $2 \mu \mathrm{M}$ iAs ${ }^{\mathrm{III}}$ ). 


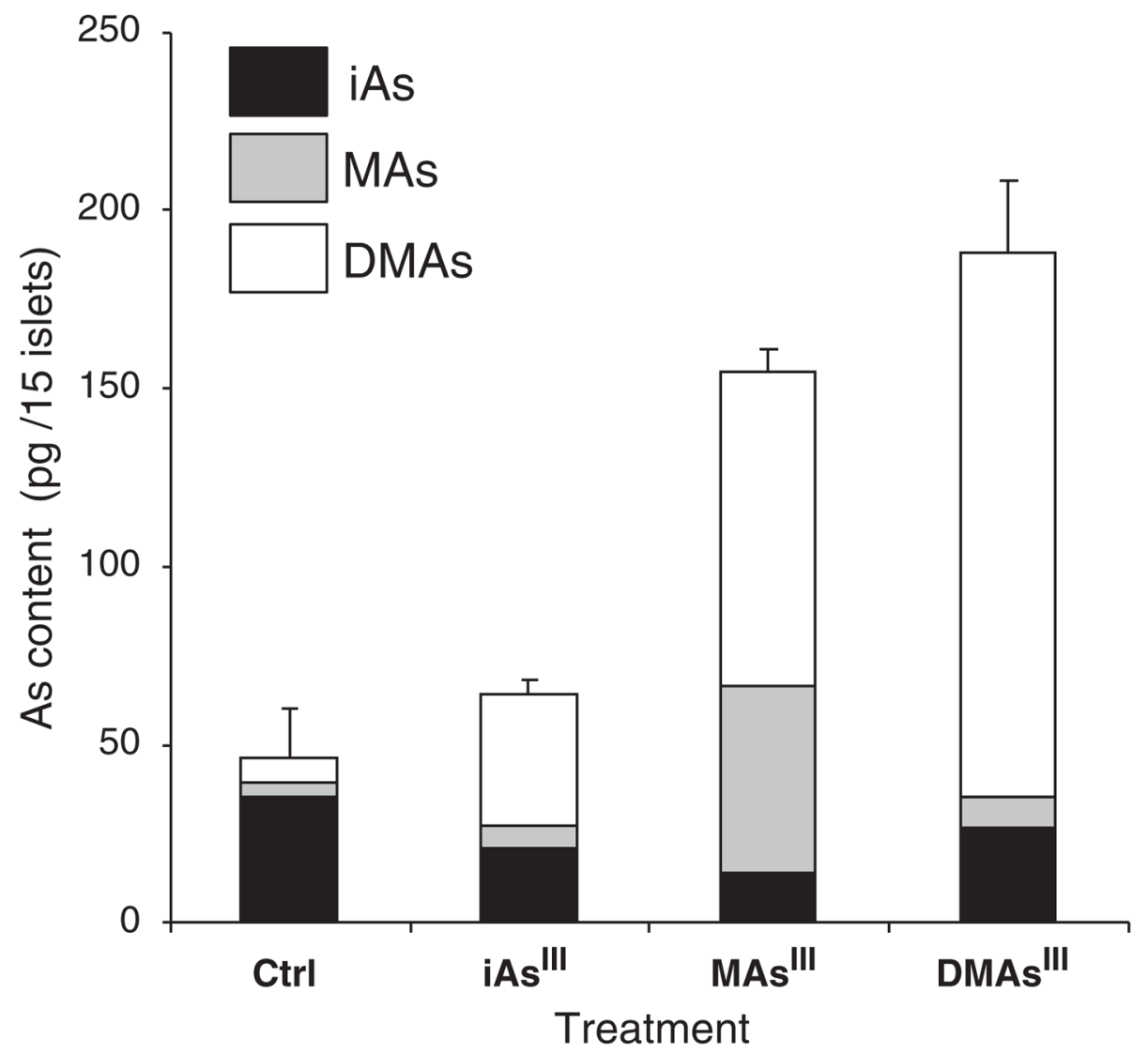

Fig. 3.

Arsenic species in pancreatic islets exposed for $48 \mathrm{~h}$ to $0.5 \mu \mathrm{M}^{\text {iAs }}{ }^{\mathrm{III}}$, MAs ${ }^{\mathrm{III}}$ or DMAs ${ }^{\mathrm{III}}$ and in control (Ctrl), unexposed islets; mean and standard error for 4 samples per treatment (15 islets per sample) are shown. 


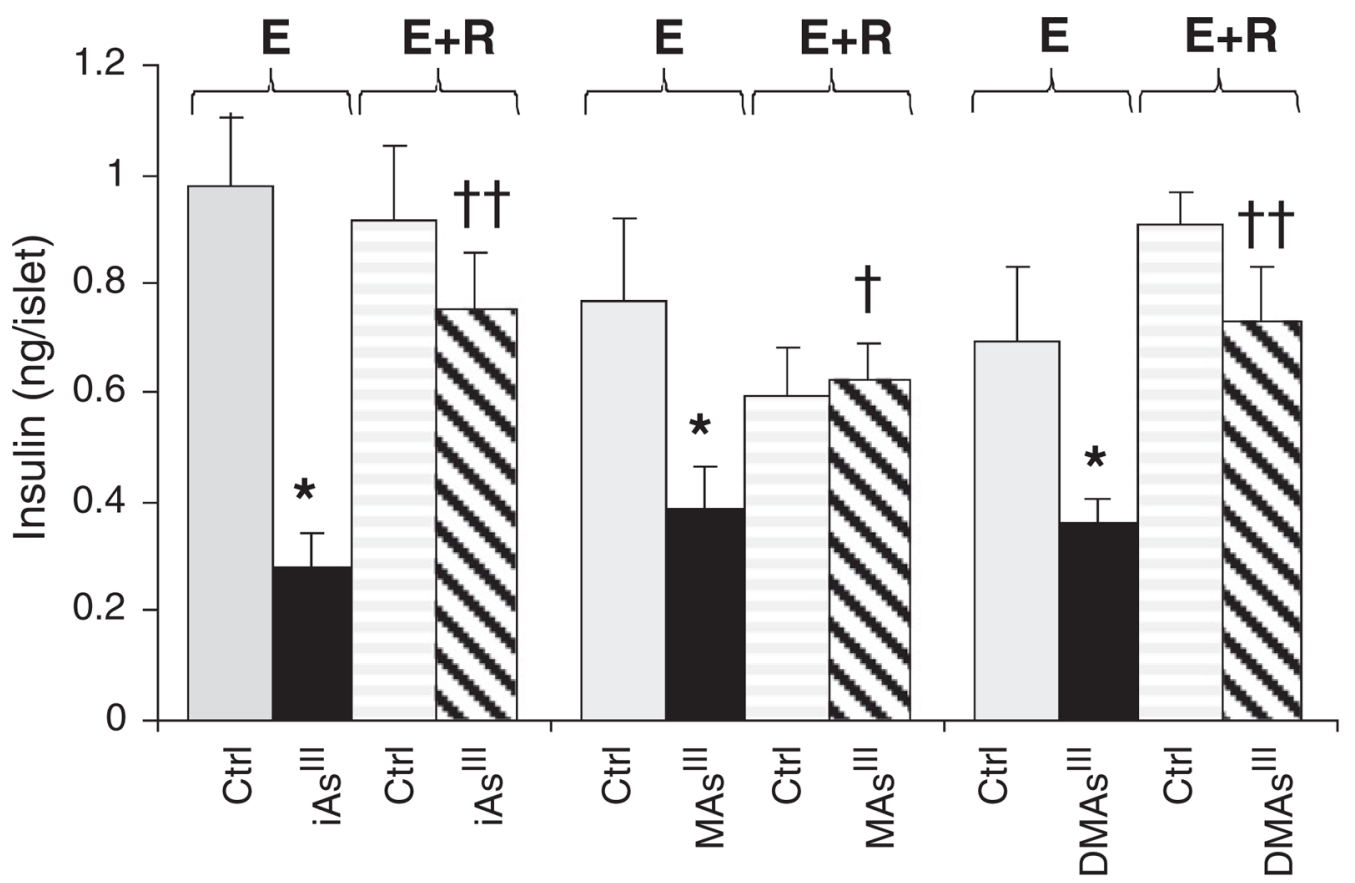

Fig. 4.

Reversibility of the inhibition of glucose stimulated insulin secretion by trivalent arsenicals: Glucose-stimulated insulin secretion by control (Ctrl) pancreatic islets and by islets exposed for $24 \mathrm{~h}$ to $2 \mu \mathrm{M}$ iAs ${ }^{\mathrm{III}}, 0.5 \mu \mathrm{M}$ MAs ${ }^{\mathrm{III}}$ or $0.5 \mu \mathrm{M}$ DMAs ${ }^{\mathrm{III}}$ before (E) and after (E+R) 24hour recovery in As-free medium; mean and standard error for 4-10 assays with 15 islets per assay are shown $(* \mathrm{p}<0.001$ for differences between exposed and the corresponding control islets; ${ }^{\dagger} \mathrm{p}<0.01$ and ${ }^{\dagger \dagger} \mathrm{p}<0.0005$ for differences between $\mathrm{E}+\mathrm{R}$ and the corresponding $\mathrm{E}$ groups of islets treated with arsenicals). 